\title{
Flipbook KVISOFT Teaching Development Language about the Leaf of Historical Tradition in SMA Negeri Karang Pandan
}

\author{
Isa Maryati ${ }^{1}$, Leo Agung $^{2}$, Musa Pelu ${ }^{3}$ \\ ${ }^{1}$ Postgraduate Program in History Education Department, Universitas Sebelas Maret, Surakarta, Indonesia \\ ${ }^{2,3}$ Universitas Sebelas Maret, Surakarta, Indonesia
}

\begin{abstract}
This study aims to determine whether through the development of flipbook learning media on the material of the legacy of historical traditions can be used to improve student achievement in its function, namely as a learning resource for students in the classroom. This research method includes research and development $(R \& D)$. The subjects of this study were 36 students of class X MIPA 1 consisting of 26 female students and 10 male students. The instruments used in this study were interview sheets or questionnaire sheets and observation sheets. The results of this research are in the form of electronic books, flipbooks, legacy of historical traditions. The data taken at the time of the research are validity test data and reliability test data. Based on the results of the research, it shows that the development of flipbook learning media on the material of the legacy of historical traditions as a source of student learning is effective to improve student achievement in history subjects with the results of pre test $=$ $67.2 \%$, post-test $1=72.1 \%$, and post. -test $2=78.14 \%$. This electronic book, in the form of a flipbook, from the heritage of historical traditions, is used as a teaching and learning resource at SMA N Karangpandan.
\end{abstract}

\section{Keywords}

flipbook; history;

learning achievement

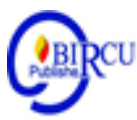

\section{Introduction}

Education is one of the human means towards nation building and the progress of the country itself. According to Widyawati (2016), education plays an important role in creating quality individuals. Education does not only educate students to become intelligent human beings, but also educate their character to have good character. Today education in Indonesia in particular is still considered by many to have no problem with the role of education, especially in the scope of the curriculum whose mission is to educate Indonesian children. Seeing the reality in the field that the character of students does not reflect good behavior. Character formation through a hidden curriculum is seen as an important requirement as a complement to the formal curriculum. Education is a very interesting world to be discussed and studied. Various problems are popping up more and more. It cannot be separated with the growing development of human thought in seeing the phenomena that occur and human awareness of the importance of education. Various changes that are always developing make humans are required to actively solve problems that occur (Lubis, 2019). Harahap (2019) states development is a process of developing a product and validating the effectiveness and efficiency of the product to be produced. Education in Indonesia in the last decade has reaped many problems including the weak character of the young generation where the success of a nation can be seen from the character of the younger generation. 
Seeing these problems, there needs to be some breakthroughs, one of which can be done through character inculcation that is applied in schools through classroom learning and other activities such as extracurricular activities (Siregar et al, 2020).

Education is a conscious and planned effort to create an atmosphere of learning and the learning process so that students actively develop their potential to have religious spiritual strength, self-control, personality, intelligence, noble character, and skills needed by themselves, society (National, 1982). Sitorus (2019) states that Education is one way to produce quality Human Resources (HR) with experience changes in knowledge, skills and attitudes. These changes can be a capital to improve self competence in facing the era of globalization that always undergo the change. (Gaol and Sitepu, 2020)

Siregar (2020) states that education does not only educate students to become intelligent human beings, but also educate their character to have good character. Today education in Indonesia in particular is still considered by many to have no problem with the role of education, especially in the scope of the curriculum whose mission is to educate Indonesian children. Seeing the reality in the field that the character of students does not reflect good behavior. Character formation through a hidden curriculum is seen as an important requirement as a complement to the formal curriculum. (Martono et al, 2020)

Education is the foundation of a nation and a measure of national progress. This was also expressed by Yuliasari (2017) that education is an investment in human resources in the long term that has strategic value for the continuity of human civilization in the world. This statement shows that education is the main asset of the young generation to shape a world that is advanced and full of technology. Therefore, in the field of education, innovation is needed with advances in technology and education today without changing educational values. One branch of science that has many benefits and can develop abilities, skills, humanity, and creativity is history lessons.

Education is key to the progress of a nation. As Iwantoro has put forward (2014:53) education is a very important issue in the development of this nation and the country. The purpose of Education is to direct the growing potential of learners to be a man of pious care to the One God Almighty, qualified, possessed of sublime pekerti ability and virtuousness. Education has a very strategic role in determining the direction of the forthcoming of the nation's quality of community knowledge. (Musdiani et al, 2019)

History lessons are one of the subjects in the world of education that have an important role in life. The milestone of this nation's history is when humans find out about its history. According to Purwanta (2019), through historical education, people understand who they are socially, nationally and even globally.

According to Supriya (2009: 26), historical learning is a study that describes humans in the past with all aspects of human activity such as politics, law, military, society, religion, creativity (related to art, music, Islamic architecture), science and intellectuals. This is in line with Zahra (2017: 2) that history learning is expected to be able to build awareness, knowledge, insight, and values about the environment that is proper for oneself and the community to live in. In addition, history learning plays a role in efforts to build national character and instill cultural values.

Historical sites are learning resources that can use outdoor learning models. Outdoor learning model is able to hone student creativity in lectures, foster a spirit of independence, cooperation between students, train to control emotions and foster scientific attitudes suitable for use in historical sites. Historical sites are related to areas that have cultural heritage objects that can be used as learning resources. Learning local history is the study of the life of a particular community or community in the dynamic development of human 
life. Meanwhile, Warsino in Rizqi (2020) believes learning local history can increase a sense of concern and interest in their area. Based on these two views, the researcher seeks to foster interest in student learning at the Vocational High School in Pringsewu Regency through local history material. (Rosmiati et al, 2020).

Widget (1989: 30) explains that history learning is a field of science that has the goal that each student builds awareness of the importance of time and place which is a process of the past, present, and future so that students realize that they exist. part of the nation. Indonesia has a sense of pride and love for the country which can be implemented in various lives, both nationally and internationally. This is in accordance with Kasmadi (1996: 13), the purpose of learning history is to instill the spirit of nationality, love for the country, nation, and state. History learning has material that can develop the potential of students to recognize national values that were fought for in the past, maintained, and adapted for the present, and developed in the future. History reveals that the events that occurred in the past were not just fictions, but real events and events that occurred in the past, for example the persistence of warriors or heroes against the invaders to defend the dignity of the nation.

Problems that arise when history learning takes place must be resolved immediately. Such as problems in the learning process. The use of less varied methods, the lack of use of learning and learning media that prioritizes learning outcomes without paying attention to the ongoing learning process, causes history learning to seem monotonous and less creative.

While the purpose of learning history is to instill character education, if the learning process is less than optimal, this goal is not fully conveyed to students.

The school that is the object of this research, in terms of the use of learning media has not been utilized optimally, the teaching materials used are still using the old method, and students do not understand what is contained in the teaching material. As a result, students easily feel bored with teaching materials that are still monotonous. Therefore it is necessary to have innovation and creativity in learning history so that students feel happy and understand the subject matter.

Sari et al (2017) wrote in their research that the learning media used by teachers received a good response from students. This was also conveyed by Supriadi (2015) that learning using teaching materials has a positive impact. According to Sriwahyuni (2019: 146), electronic teaching materials are teaching materials whose content is in electronic form, can be in the form of audio, audiovisual, or interactive media. Sriwahyuni also revealed that in his research, electronic teaching materials were a set of materials that were arranged coherently and systematically and displayed the competency needs that students had to master in the learning process combined in interactive multimedia. For example books such as e-books, e-magazines, interactive learning slides, and many more. Therefore, researchers are interested in developing e-module teaching materials using the Kvisoft Flipbook Maker application.

The Kvisoft Flipbook Maker application is an application that supports learning media that will help in the teaching and learning process because this application is not only fixated on writing but can include video and audio which can make interactive learning media interesting. According to Susanti (2015), e-books that use the Ubisoft flipbook maker application can be accessed offline and do not have to pay a fee because they are in soft file.

Previous researchers have developed e-book teaching materials, including Siti Lailun et al. (2020) which states that the development of the Flip Book History learning media can improve student achievement in its own function, namely as a source of student 
learning. The development of the Flip Book learning media was effective in increasing the learning achievement of history subjects for class $\mathrm{X}$ students with the pre-test results of $60.8 \%$, post-test $167.8 \%$, and post-test $271.6 \%$. The difference between the author's research was conducted online, whereas this research was conducted directly in offline schools.

Another research was also conducted by Edi Wibowo (2018), with the results of emodule research using the Ubisoft flipbook maker application that was produced in this study which was considered feasible for use in learning because student responses were very interesting. The difference in this research is not to develop teaching materials but to develop learning media for Kvisoft Flipbook Maker, while in the research the authors develop e-module teaching materials with the Kvisoft Flipbook Maker application.

Based on relevant previous research, there are differences and updates from each research carried out. The difference and this update lies in using the eBook Kvisoft Flipbook Maker as a tool for creating e-modules. The purpose of this study was to develop historical e-book teaching materials using the Kvisoft flipbook maker application to improve student learning achievement in its function as a source and historical teaching material.

\section{Research Methods}

The research method used by the author in this study is research and development. The research and development method $(\mathrm{RnD})$ is a research method used to produce certain products and test the effectiveness of the products used. This research and development is designed using the ADDIE development model (Analysis, Design, Development, Implementation, and Evaluation).

The analysis was carried out to determine the learning needs of students, what the teacher would teach, and the components that were expected to be mastered by students after learning activities in class.

Design after the student's learning needs are identified, the next step is to design the learning that will be used in the classroom.

Development is in the form of making or producing learning specifications that have been determined at the design stage, namely making e-books using the Kvisoft Flipbook Maker application.

The implementation in the implementation of this research is designed with four stages, namely planning, implementing action, observation, and reflection. This evaluation stage is the final stage of the ADDIE development model series.

\section{Discussion}

The results of the preliminary trial data showed that the number of test item data obtained by students in one class was 1,620 with an average percentage in one class of $67.2 \%$ of the total number of students, namely 36 students. Researchers used $\mathrm{r}$ table, namely 0.396 . The $5 \%$ data significance level was 0.486 and the $1 \%$ data significance level was 0.606 .

The results of post-test 1 research data showed that the number of questionnaire data found by students in one class was 1,750 with an average percentage of one class of $72.1 \%$ with 36 students. 
The results of research data in posttest 2 questions found that the number of questionnaires obtained by students in one class was 1830 with an average presentation in one class of $78.14 \%$.

This study aims to determine student learning outcomes with teaching materials in the form of e-books developed using a flipbook maker application on material from historical traditions. This $\mathrm{RnD}$ research uses the ADDIE stage. The stages of research that have been carried out in this study are 1) Analysis, in the form of an analysis of the needs needed by the teacher so that student learning achievement increases. Needs analysis can be done using a questionnaire; 2. design in the form of design, data collection, and design of sources and teaching materials as well as electronic production; 3. Development in the form of making resources and teaching materials from historical traditions using a flipbook maker application. after making the e-book, validation and revision is completed before proceeding to the next stage; 4. Implementation, in the form of online implementation stages in the classroom; 5. Evaluation, the last stage of the $\mathrm{RnD}$ research is the evaluation stage. In the ADDIE model series, this stage is carried out starting from the first stage of research. The final result of this research is an electronic learning resource using the FlipBook Maker on material from historical traditions. The difference between this research product and previous research products is that the teaching materials are delivered not only with sentences but with learning videos that can explain material that cannot be conveyed through writing.

\section{Conclusion}

Based on the development research that has been carried out and the discussion that has been described above, it can be concluded that the results of the study of learning resources are in the good category with the last post test percentage of eleven $78.14 \%$. The development of an e-book based on a flipbook maker on material from historical traditions can be a solution to the need for innovative teaching materials that can improve student learning achievement. In addition, based on the results of field tests, it was found that this flipbook-based e-book could improve student learning achievement based on pre-test and post-test. Suggestions for further research are to continue the development of more specific teaching materials with different materials with a suitable scientific approach.

\section{References}

Gaol, R., and Sitepu, A. (2020). Budapest International Research and Critics in Linguistics and Education (BirLE) Journal. Budapest International Research and Critics in Linguistics and Education (BirLE) Journal. P. 1696-1703.

Kasmadi, Hartono. (1996). Model-model dalam Pengajaran Sejarah. Semarang: Ikip Semarang Press.

Lailun, Siti et al. (2020). Pengembangan Media Flip Book Berbasis Peninggalan Megalitikum Sebagai Sumber Belajar Untuk Meningkatkan Prestasi Belajar Siswa kelas X PM SMK Trunojoyo Jember Ajaran 2018/2019. Sandhyakala: Jurnal Pendidikan Sejarah, Sosial dan Budaya Vol. 1 No. 1 Januari 2020.

Martono, T., et al. (2020). The Effectiveness of High School Affirmations (ADEM) Repatriation: Empirical Evidence from Central Java and Special Region of Yogyakarta, Indonesia. Budapest International Research and Critics in Linguistics and Education (BirLE) Journal. P. 1841-1847 
Musdiani, et al. (2019). Analysis the Role of Headmaster in Applying Quality of Education in Primary School Districts, Aceh Barat. Budapest International Research and Critics in Linguistics and Education (BirLE) Journal. P. 27-35.

Purwanta, Hieronymous. (2019). Hakekat Pendidikan Sejarah. Surakarta: UNS Press.

Rosmiati, et al. (2020). Ombilin Coal Mine Site: History and Potential as a Learning Source for the History of the Economy Based on Outdoor Learning. Budapest International Research and Critics in Linguistics and Education (BirLE) Journal. P. $1343-1352$

Sapriya. (2009). Pendidikan IPS Konsep dan Pembelajaran. Bandung: PT Remaja Rosdakarya.

Sari, A. U., Farida, \& Putra, F. G. (2017). Pengembangan Media Pembelajaran Berbantuan Web Dengan Pendekatan Bangun Ruang Sisi Datar. In Seminar Nasional Matematika dan Pendidikan Matematika 2017 (pp. 209-214).

Siregar, S., et al. (2020). Extracurricular Implementation of Islamic Education in Character Building Students in MTs EX PGA UNIVA Medan. Budapest International Research and Critics in Linguistics and Education (BirLE) Journal. P. 965-973.

Supriadi, N. (2015). Mengembangkan Kemampuan Koneksi Matematis Melalui Buku Ajar Elektronik Interaktif (BAEI) yang Terintegrasi Nilai-Nilai Keislaman. Al-Jabar : Jurnal Pendidikan Matematika, 6(1), 63-73.

Yuliasari, E. (2017). Eksperimentasi Model PBL dan Model GDL Terhadap Kemampuan Pemecahan Kelas X Multimedia SMK Negeri 3 Singaraja. Jurnal Pendidikan Teknologi Dan Kejuruan, 14(1), 40-49.

Wibowo, Edi. (2018). Pengembangan Bahan Ajar Menggunakan Aplikasi Kvisoft Flipbook Maker Materi Himpunan. Bandar Lampung: Jurnal Matematika, 1 (2), 2018, 147-156.

Widja, I Gede. (1989). Dasar-Dasar Pengembangan Strategi serta metode pengajaran Sejarah. Jakarta: Departemen Pendidikan dan Kebudayaan Direktorat Jenderal Pendidikan Tinggi Proyek Lembaga Pendidikan Tenaga Kependidikan.

Widyawati, S. (2016). Pengaruh Kemampuan Koneksi Matematis Siswa terhadap Prestasi Belajar Matematika Ditinjau dari Gaya Belajar pada Materi Bangun Ruang Sisi Datar Siswa Kelas IX SMP di Kota Metro. Iqra': Jurnal Kajian Ilmu Pendidikan, 1(1), 47-68.

Zahro, Mustika et al. (2017). The Implementation Of The Caracter Education In History Teaching. Jurnal Historica: ISSN No. 2252-4673 Vol. 1 (2017) Issue 1. 